\title{
High Abundance of the Introduced Mourning Gecko (Lepidodactylus lugubris) in Southwestern Grande Terre, Guadeloupe, French West Indies
}

\author{
Rafael Borroto-Páez
}

Sociedad Cubana de Zoología, AP 11900, Habana, Cuba (borroto@yahoo.com)

$\mathrm{T}$ he Mourning Gecko, Lepidodactylus lugubris (Duméril and Bibron 1836) is native to coastal areas of southeastern Asia, but has been widely introduced, and has been in the Western Hemisphere since the last century (Hoogmoed and Avila-Pires 2015). This species is considered as one of the most successful reptilian invaders (Bomford et al. 2009), with much of its success attributed to its parthenogenetic reproduction (Cuéllar and Kluge 1972). This allows a single female to start a new population, although ecological flexibility and even some behavioral characteristics of the species (Harfmann Short and Petren 2008) also favor the establishment of the species in human landscapes.

Mourning Geckos have only recently invaded the West Indies. In the Lesser Antilles, they were first seen in Guadeloupe (French West Indies) in November 2010 in southern GrandeTerre (Lorvelec et al. 2011; Gomès and Ibéné 2013) and in July 2011 in the northeastern part of Basse-Terre (Parmentier et al. 2013). Lorvelec et al. (2017) confirmed establishment and provided a chronological account of the species' expansion in Guadeloupe. Krysko and MacKenzie-Krysko (2016) reported a well-established population on North Bimini, The Bahamas. The first record for the Greater Antilles was reported by Alonso and Borroto-Páez (2017) in La Habana, Cuba, a locality with a confirmed presence of the species since 2008 . Most recently, the species was reported from Grand Cayman Island (Goetz and Burton 2018).

The introduction of non-native species can have a dramatic effect on insular reptilian assemblages (Case and Bolger 1991; Smith et al. 2012). Despite the invasiveness of L. lugubris, little information is available related to invasion dynamics, populations levels, and abundance in anthropic or natural habitats. Here we provide new information about the abundance of L. lugubris in a tourist zone on Grande Terre, Pointe de la Verdure, Le Gosier, Guadeloupe in May 2018.

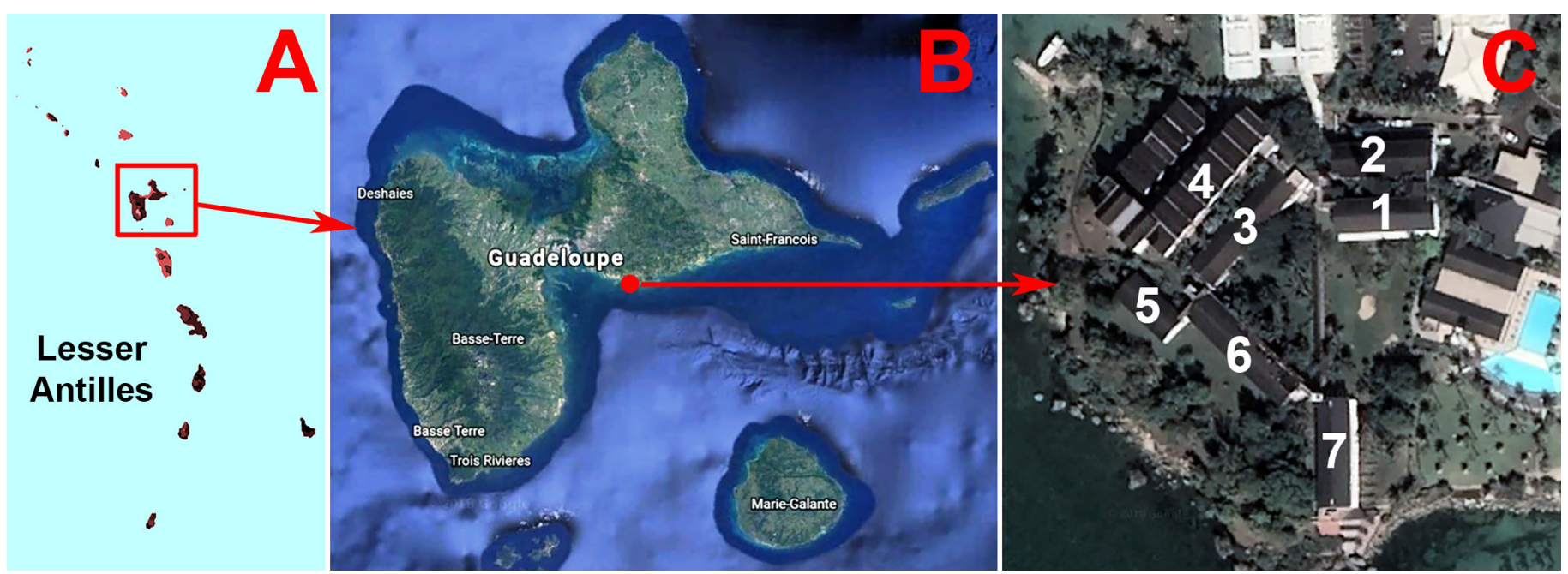

Fig. 1. (A) Map of the Lesser Antilles with Guadeloupe in red box. (B) Google Earth ${ }^{\odot}$ image of Guadeloupe showing the location of La Creole Beach Hotel \& Spa in Pointe de la Verdure, Le Gosier, southwestern Grande Terre (red dot). (C) Aerial view of La Creole Beach Hotel \& Spa showing the buildings where Mourning Geckos (Lepidodactylus lugubris) were counted: 1 = Acelia; 2 = Gorgones; 3 = Manicina; 4 = Mahogany; 5 = Atya; 6 = Chenolia; 7 = Corail. 
Rapid assessment methods (RAM) are preliminary screenings that often are employed prior to lengthier scientific inventories; they can provide quick answers to applied questions, identify conservation priorities, and alert conservation decision-makers (Abate 1992). I used RAM to assess the relative abundance of the Mourning Gecko at La Creole Beach Hotel \& Spa, Pointe de la Verdure, Le Gosier, in southwestern Grande Terre, Guadeloupe (Fig. 1), during the 3rd Caribaea Initiative Research \& Conservation Workshop (www.caribaea. org) from 28 May to 1 June 2018. This site is very close to the locality reported by Gomès and Ibéné (2013) in Le Gosier, Pointe de la Verdure (16.205556, -61.499222; elev. 8 m), which corresponds to location \#5 in Lorvelec et al. (2017).

During three consecutive days (28-30 May), I counted all individuals observed during one-hour periods while walking slowly along a line-transect through the corridors (25-60 $\mathrm{m}$ in length) of different floors of buildings using a headlamp when necessary (most corridors were illuminated). The perimeter of the seven buildings was $533 \mathrm{~m}$ and the combined area $7,960 \mathrm{~m}^{2}$. Individual were identified as adults or juveniles based on size. I used a cell phone camera to record the first images of individual animals and to confirm the species as L. lugubris (Fig. 2).

I quantified abundance as the number of geckos observed in each building on each day, the overall number of individuals observed during the three days, and the number of geckos encountered per square meter. Encounter rates were based on the number of individuals counted per minute of observation and the total number of different individuals was determined by the sum of the maximum daily number of individuals observed in each building, thus avoiding repeated counts of the same individuals.

Weather conditions varied, with wind and light rain on the first two days but not during the third. Average weather conditions in May at Le Gosier are $23.9^{\circ} \mathrm{C}\left(19.5-28.3{ }^{\circ} \mathrm{C}\right), 70 \mathrm{~mm}$ of precipitation, $78 \%$ relative humidity, and 14 days of rain.
I observed geckos mainly on ceilings and high on walls in almost all of the indoor corridors of the hotel, especially in buildings with guest rooms and close to light sources. This was in marked contrast with other parts of the complex, such as the reception area and the restaurant and bar, where I saw only a single Tropical House Gecko (Hemidactylus mabouia). Numbers of geckos and encounter rates are presented in Table 1 . Adults accounted for $71.1 \%$ of the total number of individuals observed. Almost all adults contained visible eggs; however, I was unable to precisely assess the condition of some females that were difficult to observe in poorly illuminated areas. I also saw three Tropical House Geckos, all in areas peripheral to those densely occupied by Mourning Geckos.

Although this census was limited in time and space, it provided new and valuable insights regarding the status of this introduced gecko population. The relatively greater number of individuals observed on the third day might have been influenced by observations on that day beginning 30 min earlier than on the two previous nights, although the absence of rain might have resulted in more favorable environmental conditions.

No prior data quantified density, abundance, or encounter rates for Mourning Geckos on West Indian islands. Lorvelec et al. (2017) recorded 1-10 adults and juveniles recorded by different observers at eight different sites on Basse Terre and Grande Terre, Guadeloupe; all were near human settlements. Krysko and MacKenzie-Krysko (2016) collected 11 individuals around wall lights and lamps at tourist sites on North Bimini, The Bahamas. In Cuba, Alonso and Borroto-Páez (2017) observed only five individuals. Wiles et al. (1990) provided the only available data in the species' native distribution, reporting encounter rates of $1.8 \mathrm{animals} / \mathrm{h}$ in secondary vegetation, 2.0 animals/h in urban areas, and 3.1 animals/h in forest $(0.03-$ $0.051 \mathrm{animals} / \mathrm{min})$ on Rota, Northern Mariana Islands.

The admittedly preliminary data presented herein suggest that the number of Mourning Geckos in some parts of

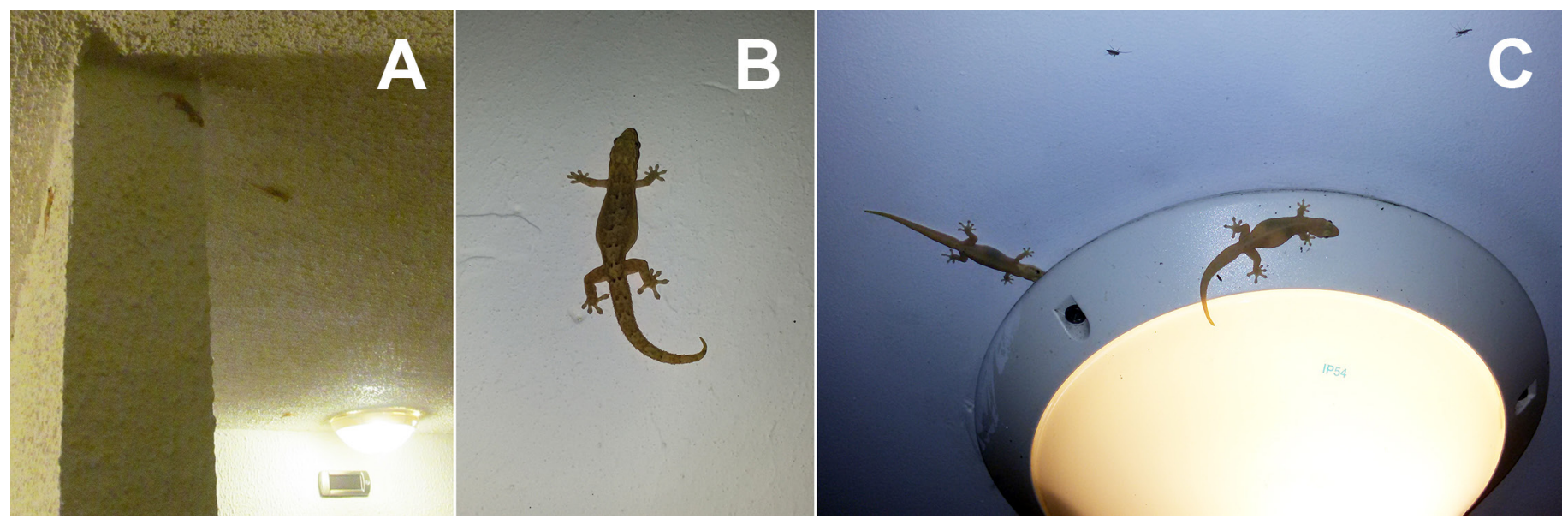

Fig. 2. (A) Four Mourning Geckos (Lepidodactylus lugubris) in a corridor of La Creole Beach Hotel \& Spa; (B) a gravid adult Mourning Gecko in typical dark color phase; (C) two gravid adults in light color phase. 
Table 1. Abundance of Mourning Geckos (Lepidodactylus lugubris) at La Creole Beach Hotel, Grande Terre, Guadeloupe, in May 2018.

\begin{tabular}{|c|c|c|c|c|c|c|}
\hline $\begin{array}{l}\text { Date } \\
\text { (duration) }\end{array}$ & Building & Adults & Juveniles & Total & $\begin{array}{l}\text { Total } \\
\text { by date }\end{array}$ & $\begin{array}{c}\text { Rate } \\
\text { (individuals/min) }\end{array}$ \\
\hline
\end{tabular}

\begin{tabular}{llccccc}
\hline 28 May & Manicina & 15 & 6 & 21 & & \\
\hline $1930-2030 \mathrm{~h}$ & Corail & 8 & 6 & 14 & & \\
\hline & Mahogany & 29 & 12 & 41 & 76 & 1.27 \\
\hline
\end{tabular}

\begin{tabular}{lllllll}
\hline 29 May & Acelia and Gorgones & 20 & 3 & 23 & & \\
\hline $1930-2020 \mathrm{~h}$ & Atya and Chenolia & 39 & 10 & 49 & 72 & 1.44 \\
\hline
\end{tabular}

30 May

\begin{tabular}{|c|c|c|c|c|c|c|}
\hline $1900-2015 \mathrm{~h}$ & Acelia and Gorgones & 16 & 8 & 24 & & \\
\hline & Mahogany & 35 & 18 & 53 & & \\
\hline & Manicina & 24 & 13 & 37 & & \\
\hline & Atya and Chenolia & 52 & 10 & 62 & 176 & 2.35 \\
\hline
\end{tabular}

Totals 238 86 324

Guadeloupe can be very high. The 190 different individuals counted in seven buildings in only three days, encounter rates of 1.27-2.35 individuals/min, and a minimum density of 0.024 geckos $/ \mathrm{m}^{2}$ clearly exceed numbers previously reported for Guadeloupe (Lorvelec et al. 2017). Also, the number of adults with visible eggs and the fact that juveniles accounted for over one-fourth of all observed individuals are indicative of continuous and highly successful reproduction of the species at this site.

In addition to the high concentration of Mourning Geckos observed at La Creole Beach Hotel \& Spa, I encountered (but did not count) individuals in the neighboring Karibea Beach hotel, on a building wall $3 \mathrm{~km}$ from the hotel, and on the ceiling of a bus stop about $6 \mathrm{~km}$ from the hotel. The number of sightings at various locations only eight years after the first report of the species on Guadeloupe could be an alert for conservation authorities. Although observed only in anthropogenic situations, in which effects on native species are likely to be negligible, the abundance of Mourning Geckos in a hotel serving national and international visitors is likely to facilitate dispersion of the species via transport to other places and countries in the baggage of tourists.

This is the first report of a high abundance of Mourning Geckos in the West Indies or for any other areas where this species has been introduced. I hope it can serve as a timely alert to conservation authorities to assess the potential risks posed by such introductions and to coordinate effective prevention protocols and control efforts.

\section{Acknowledgements}

The Caribaea Initiative extended the invitation for me to attend the 3rd Caribaea Initiative Research \& Conservation Workshop, which provided the opportunity to conduct this study. Frank Cézilly, president of the Caribaea Initiative, and Boris A. Fabres, Environmental Protection in the Caribbean (EPIC), provided useful suggestions that improved this manuscript.

\section{Literature Cited}

Abate, T. 1992. Environmental rapid-assessment programs have appeal and critics. BioScience 42: 486-489.

Alonso Bosch, R. and R. Borroto Páez. 2017. First record from Cuba of the introduced Mourning Gecko, Lepidodactylus lugubris (Duméril and Bibron, 1836). BioInvasions Records 6: 297-300.

Bomford, M., F. Kraus, S.C. Barry, and E. Lawrence. 2009. Predicting establishment success for alien reptiles and amphibians: A role for climate matching. Biological Invasions 11: 713-724.

Case, T.J. and D.T. Bolger. 1991. The role of introduced species in shaping the distribution and abundance of island reptiles. Evolutionary Ecology 5: 272-290.

Cuéllar, O. and A.G. Kluge. 1972. Natural parthenogenesis in the gekkonid lizard Lepidodactylus lugubris. Journal of Genetics 61: 14-26.

Goetz, M. and F.J. Burton. 2018) First Record of the Mourning Gecko, Lepidodactylus lugubris (Duméril \& Bibron 1836), on Grand Cayman, Cayman Islands. Reptiles \& Amphibians 25: 158-159.

Gomès, R. and B. Ibéné. 2013. Lepidodactylus lugubris (Mourning Gecko). Distribution. Caribbean Herpetology 44: 1. 
Harfmann Short, K. and K. Petren. 2008. Boldness underlies foraging success of invasive Lepidodactylus lugubris geckos in the human landscape. Animal Behaviour 76: 429-437.

Hoogmoed, M. and T.C.S. Avila-Pires. 2015. Lepidodactylus lugubris (Duméril \& Bibron 1836) (Reptilia: Gekkonidae), an introduced lizard new for Brazil, with remarks on and correction of its distribution in the New World. Zootaxa 4000: 90-110.

Krysko, K.L. and C. MacKenzie-Krysko. 2016. First report of the Mourning Gecko, Lepidodactylus lugubris (Duméril \& Bibron 1836), from The Bahamas. Caribbean Herpetology 54: 1-2.

Lorvelec, O., A. Levesque, and A.M. Bauer. 2011. First record of the Mourning Gecko (Lepidodactylus lugubris) on Guadeloupe, French West Indies. Herpetology Notes 4: 291-294.
Lorvelec, O., N. Barré, and A.M. Bauer. 2017. The status of the introduced Mourning Gecko (Lepidodactylus lugubris) in Guadeloupe (French Antilles) and the high probability of introduction of other species with the same pattern of distribution. Caribbean Herpetology 57: 1-7.

Parmentier, P., B. Ibéné, and R. Gomès. 2013. Lepidodactylus lugubris (Mourning Gecko). Distribution. Caribbean Herpetology 47: 1.

Smith, M.J., H. Cogger, B. Tiernan, D. Maple, C. Boland, F. Napier, T. Detto, and P. Smith. 2012. An oceanic island reptile community under threat: The decline of reptiles on Christmas Island, Indian Ocean. Herpetological Conservation and Biology 7: 206-218.

Wiles, G.J., G.H. Rodda, T.H. Fritts, and E.M. Taisacan. 1990. Abundance and habitat use of reptiles in Rota, Mariana Islands. Micronesia 23: 156-166. 